\title{
数值シミュレーションに基づく \\ 乙津川の樹木伐採前後の境界混合係数值の検討 EXAMINATION OF BOUNDARY MIXING COEFFICIENTS BEFORE AND AFTER DEFORESTATION IN THE OTOTSU RIVER BASED ON NUMERICAL SIMULATIONS
}

\author{
重枝 未玲 ${ }^{1} \cdot$ 朝位 $^{7_{子} 二^{2}} \cdot$ 坂本 洋 $^{3} \cdot$ 西尾 崇 ${ }^{4} \cdot$ 秋山 壽一郎 $^{5} \cdot$ \\ 樋口 直樹 6 . 石原 仁 $^{6} \cdot$ 德永 智宏 ${ }^{3}$ \\ Mirei SHIGE-EDA, Koji ASAI, Hiroshi SAKAMOTO, Takashi NISHIO, Juichiro AKIYAMA, \\ Naoki HIGUCHI, Jin ISHIHARA and Tomohiro TOKUNAGA \\ ${ }^{1}$ 正会員 博士 (工) 九州工業大学助教授 工学部建設社会工学科 (广 804-8550 北九州市戶畑区仙水町 1-1) \\ 2正会員 博士 (工) 山口大学助教授 工学部社会建設工学科 ( T 755-8611 宇部市常盤台 2-16-1) \\ 3 正会員 株式会社 建設技術研究所 九州支社河川部 (T 810-0041 福岡市中央区大名 2-4-12 CTI 福岡ビル) \\ ${ }^{4}$ 正会員 国土交通省九州地方整備局大分河川国道事務所所長 (T 870-0820 大分市西大道 1-1-71) \\ 5フェロー会員 Ph.D. 九州工業大学教授 工学部建設社会工学科 (广 804-8550 北九州市戶畑区仙水町 1-1) \\ 6 学生会員 九州工業大学大学院 工学研究科建設社会工学専攻 (同上)
}

\begin{abstract}
The boundary mixing coefficients, which is used for estimation of boundary shear stress due to vegetation in quasi $2 \mathrm{D}$ simulations, in the Ototsu river is investigated numerically. Firstly, the relation between the boundary mixing coefficients $f$ and vegetation density is examined through comparison of numerical results between quasi $2 \mathrm{D}$ and $2 \mathrm{D}$ simulations. From the relation, a value of $f$ is found to be 0.08 in the Ototsu river. And it is shown that the quasi $2 \mathrm{D}$ model can reproduce the observation data of the water level in the three different flooding when the $f=0.08$ is used . The effects of deforestation to the boundary mixing coefficient $f$ is also examined. It shows that deforestation is not effected significantly on the value of $f$ in the Ototsu river.
\end{abstract}

Key Words : boundary mixing coeffecient, flood flow, the Ototsu River, vegetation, quasi twodimensional and two-dimensional numerical simulations

\section{1.はじめに}

近年，治水と環境の調和した川作りが求められてい る . 河道内樹木は，堤防・河岸保護や生態系環境の提供 など治水・環境機能を有する反面, 適切な管理がなさ れない場合には洪水時に流下阻害となり，水位上昇な どの治水面上の問題を引き起こす場合がある . 河道内 樹木の管理法については，「河川における樹木管理の手 引き」1)などに取りまとめられており，樹木群の持つ治 水機能や環境機能を損なわないように配慮しつつ, 支 障の大きいものから必要に応じて伐採することが基本 とされている .

樹木管理を行うためには，河道内樹木が洪水流に及 ぼす影響を適切に評価できるツールが不可欠となる．光 のようなツールの一つに, 準 2 次元解析 ${ }^{2}$ がある. 現在 の河道改修計画の多くはこの準 2 次元解析結果をべー
スに検討がなされている．準 2 次元解析では，樹木群 を死水域と樹木境界で流れに働くせん断力として取り 扱う.このため，洪水時の水位を予測する上で，死水 域とせん断応力を算定するための境界混合係数 $f$ を適 切に設定することが必要となる. 現況河道と樹木繁茂 に対する樹木群の取扱いにの手法については「河川に おける樹木管理の手引き」 ${ }^{1)}$ に取りまとめられている . しかし，いずれの設定についても，痕跡水位に基づき 修正を行う必要があるために, 痕跡水位等が存在しな い樹木伐採後の $f$ 值や死水域の推定方法は確立されて いないのか実状である。

弚の一方で, 平面 2 次元解析や準 3 次元解析などの ツールもある.これらは，一般に樹木を流水抵抗として 取り扱い，乥の評価には樹木の繁茂状況に応じて設定 された抵抗係数や透過係数が用いられる. 福岡ら ${ }^{3)}$ は， 平面 2 次元解析結果と観測水位に基づき, 河道内樹木 
の透過係数の平均的な分布を推定できることを示して いる.このことは，平面 2 次元解析を用いれば，樹木繁 茂状況が洪水流に及ぼす影響を把握可能であることを 示している. 従って, 平面 2 次元解析の結果を準 2 次 元解析に反映することができれば，準 2 次元解析の枠 組みで治水面上適切な樹木繁茂状況の検討や樹木伐採 位置や量などの河道内樹木の管理をより合理的に検討 することができると考えられる．

著者らは, 平面 2 次元解析モデルを用い，河道内樹 木が大野川と乙津川の洪水流に及ぼす影響および河道 内樹木が大野川から乙津川への分派流量に及ぼす影響 などについて検討した結果，平面 2 次元解析モデルに より洪水時の河道内水位のみならず分派流量までの再 現可能であることを示した ${ }^{4), 5)}$.

本研究は, 大野川と乙津川の治水と環境保全とが調 和した樹木管理基準を明確にすることを目的としてい る.ここでは，乙津川を対象に，まず，洪水流量の異な る 3 つの出水に対して平面 2 次元解析モデルが十分な 精度で痕跡水位を再現できることを示す．次に，平面 2 次元解析と準 2 次元解析の比較から，乙津川の平均的 な樹木境界混合係数 $f$ の推定を行い，この $f$ 值を用い た準 2 次元解析の予測精度について検討する . 最後に， 樹木伐採が樹木混合係数 $f$ に及ぼす影響を数值シミュ レーションに基づき検討する．

\section{2. 乙津川の概要}

本研究で対象とする乙津川は, 大分県の中央部を貫 流する一級河川大野川の派川である (図-1) . 光の延長 は $10.9 \mathrm{~km}$ で図-1 では全区間の内, 距離標 $0 \mathrm{~km} \sim$ 大野 川からの分流地点までの区間を示している．乙津川の 河道特性による河道区分はセグメント $2-2$ に対応する 計画高水流量は大野川から分流堰より配分される流量 $1,500 \mathrm{~m}^{3} / \mathrm{s}$ である .乙津川の河道内樹木は, 距離標 3.4 〜 $5.6 \mathrm{~km}$ 区間に集中しており，メダケ等の竹林が多く， 兴のほとんどは低水路沿いに位置する.平成 17 年 9 月 の出水では計画高水流量を下回る流量 $\left(1142 \mathrm{~m}^{3} / \mathrm{s}\right)$ で あったにも関わらず, 高田橋水位観測所 (図-1)におい て計画高水位を $0.32 \mathrm{~m}$ 超えたことが報告されている ${ }^{6)}$ 。

\section{3. 境界混合係数}

準 2 次元解析では, 河道内樹木は (1) 死水域として流 積を減少させること，(2) 流れと樹木の境界に働くせん 断応力 $\tau$ を加えることで取り扱われる.(1)の死水域に ついては, 樹木繁茂状況の粗密により死水域を割り引 くことなどの基準が存在するが，一般にはある程度の 樹木が密生していれば樹木繁茂範囲の全てを死水域と して取り扱われることが多い，また，(2)のせん断応力 $\tau$ は, 境界混合係数 $f$ を用いて式 (1) で定義される .

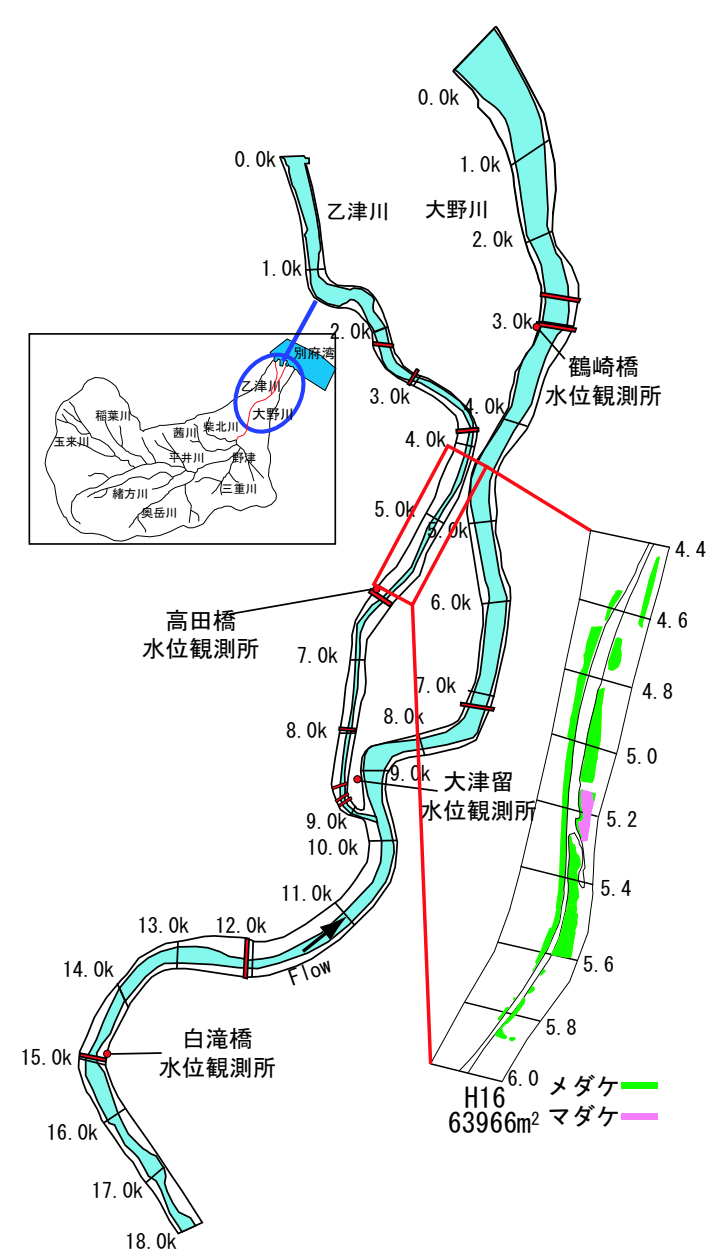

図-1 乙津川の概要

$$
\tau=\rho \cdot f \cdot(\Delta u)^{2}
$$

ここに,$\rho=$ 水の密度 , $\Delta u=$ 樹木群内外の流速差であ り，樹木群内の流速は光の外側の流速に比べ非常に小 さいために通常 0 として計算される.しかし, 実際に は樹木群繁茂状況によっては樹木内にも流れが生じて いるために, 樹木群内の流速は 0 とならない．このた め, 樹木群内の流れが洪水流に及ぼす影響は, 境界混 合係数 $f$ 值に陰的に含まれることになる. 従って, 痕 跡水位に基づく境界混合係数の修正の必要性が生じる.

境界混合係数 $f$ は，樹木の位置により推奨値があり， 樹木か堤防に接している場合は $f=0.03$, 樹木が河道の 中央にある場合には $f=0.10$ が用いられる . また , 福 岡・藤田らの実験 ${ }^{2}$ から樹木が堤防に接した場合と河道 の中央にある場合とにわけ, $f$ を求める理論式を提案し ている、樹木群が河道の中央にある場合は次式のよう になる．

$$
\begin{array}{ll}
\frac{K_{s} \sqrt{h}}{u_{m} \sqrt{b}} \leq 0.4 & f=0.072 \frac{K_{s} \sqrt{h}}{u_{m} \sqrt{b}} \\
\frac{K_{s} \sqrt{h}}{u_{m} \sqrt{b}}>0.4 & f=0.017+0.029 \frac{K_{s} \sqrt{h}}{u_{m} \sqrt{b}}
\end{array}
$$

ここに, $K_{s}=$ 透過係数, $h$ は水深, $u_{m}=$ 樹木群に接す る分割断面での平均流速， $b=$ 樹木群幅である. 


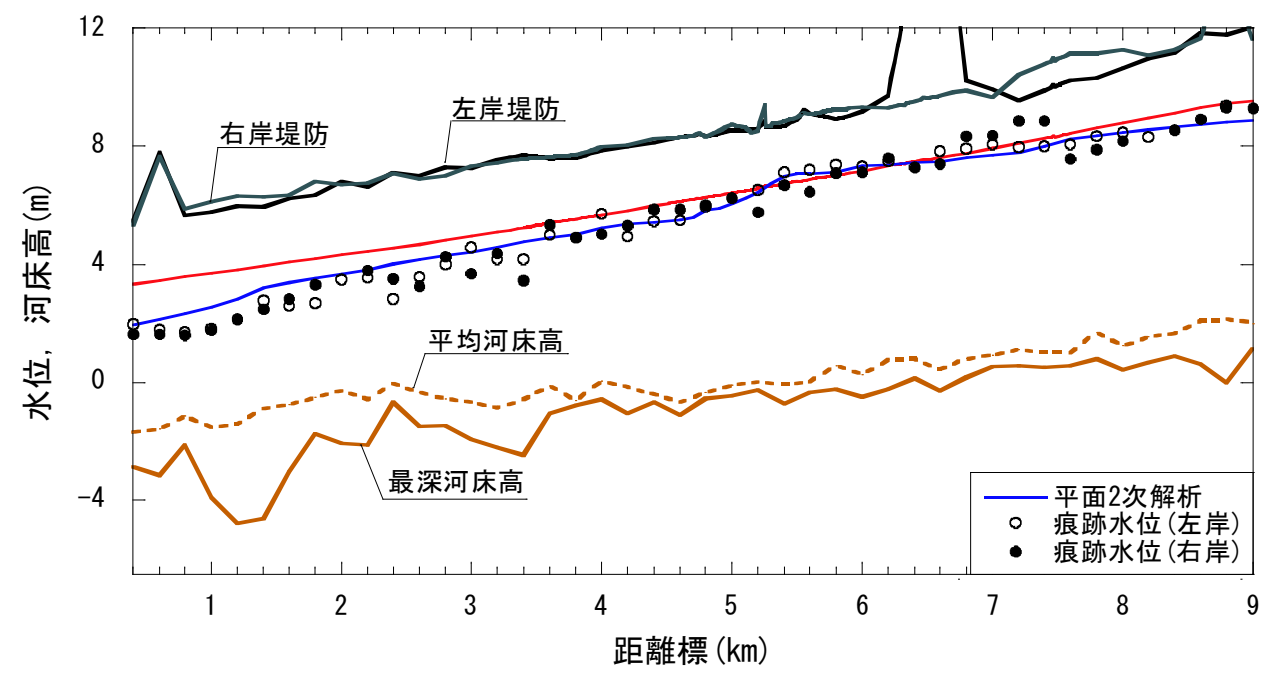

図-2 平成 17 年 9 月の出水時の痕跡水位と平面 2 次元解析結果との比較

\section{4. 数值解析の概要}

平面 2 次元解析には著者等が開発した SA-FUF-2DF モデル ${ }^{7)}$ を, 準 2 次元解析には財団法人国土技術研究セ ンターが作成した河道計画シミュレータ8)を用いた 。

計算に用いた河道縦横断面は, 平成 13 年の測量デー 夕を用いた . 粗度係数 $n$ については, 「大野川河道技術資 料」9)で用いられた值を用いた。低水路については河床 材料の粒径に基づき $n=0.034 \sim 0.036$ の範囲で, 高水敷 については水深と植生の高さの関係に基づき $n=0.025$ 〜0.048 の範囲 で与えた .

樹木群の繁茂位置については平成 11 年，17 年につ いては「河川水辺の国勢調査 平成 11 年度, 16 年度版 大野川水系大野川植生調査報告書」に基づき作成した 平成 9 年についてはデータが存在しなかったため, 平 成 6 年と 11 年のデータを内挿することで作成した .な お，樹木群については，乙津川の樹木群のほとんどを 占有しているマダケ, メダケ群集，および常緑広葉樹 林 (ムクノキータブノキ群落)（距離標 $6.2 〜 6.6 \mathrm{~km}$ の み繁茂) を対象とした。

SA-FUF-2DF モデルでは樹木群は $x$ 方向, $y$ 方向の

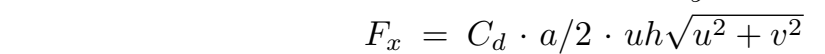
$F_{y}=C_{d} \cdot a / 2 \cdot v h \sqrt{u^{2}+v^{2}}$ で表される空間平均され た流体力項を付加することで取り扱われる ${ }^{7)}$.ここに， $a=$ 樹木群密度パラメーター $(=d \cdot N), d=$ 樹木の投影 幅, $N=$ 樹木密生度 $\left(\right.$ 本 $\left./ \mathrm{m}^{2}\right)$ および $C_{d}=$ 抵抗係数であ り，各パラメーターは，樹木繁茂状況に応じて設定さ れる. 樹木群密度パラメーター $a$ については, 現地で 行ったコドラード調査結果 ${ }^{10)}$ をとに設定した . 抵抗 係数 $C_{d}$ については, 植生繁茂状況で光の值は変化する と考えられるが，ここでは円柱の抵抗係数 $C_{d}=1.2^{2)}$ を 用いた．なお，準 2 次元，平面 2 次元解析のいずれも， 非水没状態として樹木群を取り扱った。

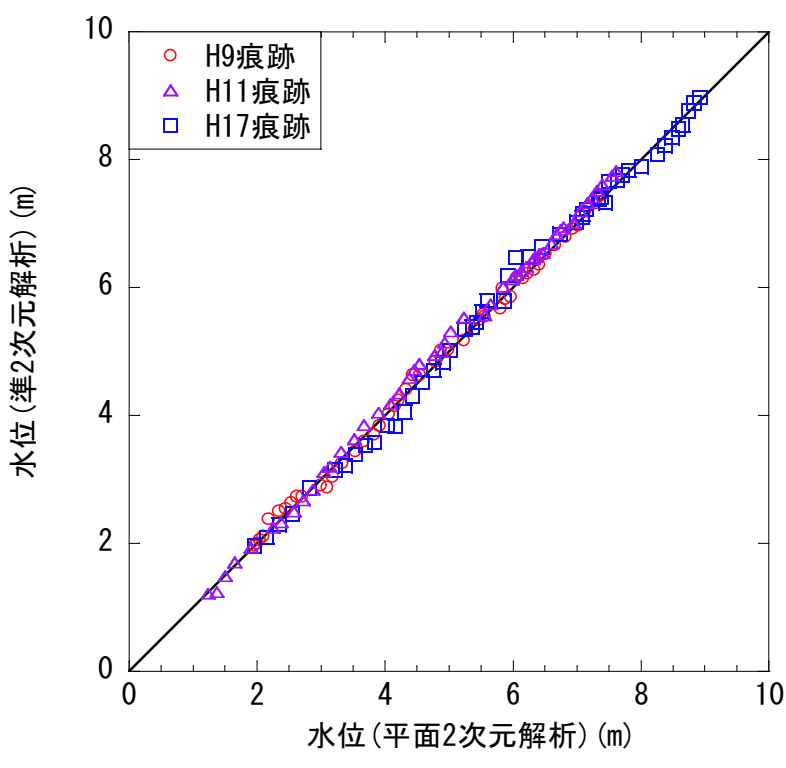

図-3 平面 2 次元解析と準 2 次元解析との比較 (洪水痕跡)

境界条件として上流端 (距離標 $9.0 \mathrm{~km}$ ) に流量を，下 流端 (距離標 $0.4 \mathrm{~km}$ ) に水位を与えた . 痕跡水位との比 較では, 高田橋水位観測所での痕跡水位から算出され た出水時の流量と痕跡水位を, 計画高水流量時の解析 では計画と同樣に,計画高水流量 $1500 \mathrm{~m}^{3} / \mathrm{s}$ と淡水と海 水の密度差による水位上昇を考慮した朔望平均満潮位 と河口水深× $2.5 \%$ の和 T.P1.158m を与えた .

\section{5. 結果と考察}

(1) 平面 2 次元解析モデルの予測精度の検証

まず, 平成 $9,11,17$ 年に発生した流量 $\left(\mathrm{H} 9: 572 \mathrm{~m}^{3} / \mathrm{s}\right.$, $\left.\mathrm{H} 11: 725 \mathrm{~m}^{3} / \mathrm{s}, \mathrm{H} 17: 1142 \mathrm{~m}^{3} / \mathrm{s}\right)$ の異なる 3 つの出水 に対して，痕跡水位に基づき平面 2 次元解析モデルの 検証を行った . 図-2 は, 平成 17 年の出水での平面 2 


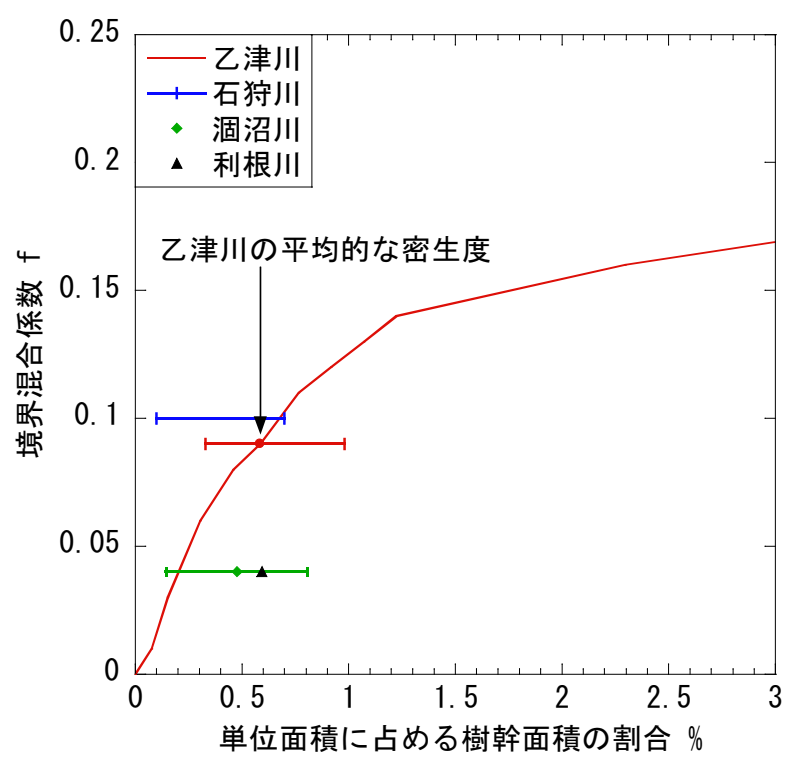

図-4 境界混合係数と単位面積中の樹木面積との関係

次元解析の河道中心軸上の水位と痕跡水位との比較を 行ったものである. この図から，平面 2 次元解析は痕 跡水位を十分な精度で再現していることが確認できる また，いずれの出水に対しても同程度の精度の結果が 得られた .これらより, 本平面 2 次元解析は十分な精 度で洪水流を再現できることが確認できる．

\section{（2）樹木伐採前の境界混合係数 $f$ 値の検討と妥当性 の検証}

先述したように，樹木繁茂状況によっては樹木群内 の流れが生じ, 境界混合係数 $f$ 值に影響を及ぼす. 光 こで，乙津川の平均的な樹木繁茂面積の割合に対する 境界混合係数值を把握することを目的として, 計画高 水流量時について単位面積中に占める樹木繁茂面積の 割合を変化させた平面 2 次元解析と境界混合係数 $f$ を 変化させた準 2 次元解析を行い, 両解析結果が一致す るような単位面積中に占める樹木繁茂面積の割合と境 界混合係数 $f$ との関係を調べた . なお，先述したよう に乙津川は，竹林が多いことから樹木繁茂面積は樹幹 面積としている．また，低水路沿いに繁茂している樹 木が多いため，ここでは樹木が河道の中央にある場合 の境界混合係数についてのみ検討している .

図-3 は, 各距離標について, 平面 2 次元解析と準 2 次元解析で得られた河道中心軸上の水位の比較を行っ たものである .これより，平面 2 次元解析と準 2 次元 解析は直線上に集中しており, 両結果が一致している ことか確認できる .

この結果を用い樹木繁茂面積の割合と境界混合係数 $f$ との関係を調べたものが, 図-4である . 図中には, 石 狩川 ${ }^{11)}$, 涸沼川 ${ }^{12)}$, 利根川 ${ }^{13)}$ の樹木混合係数 $f$ につい ても併せて示している. また , 図中のプロットは平均値

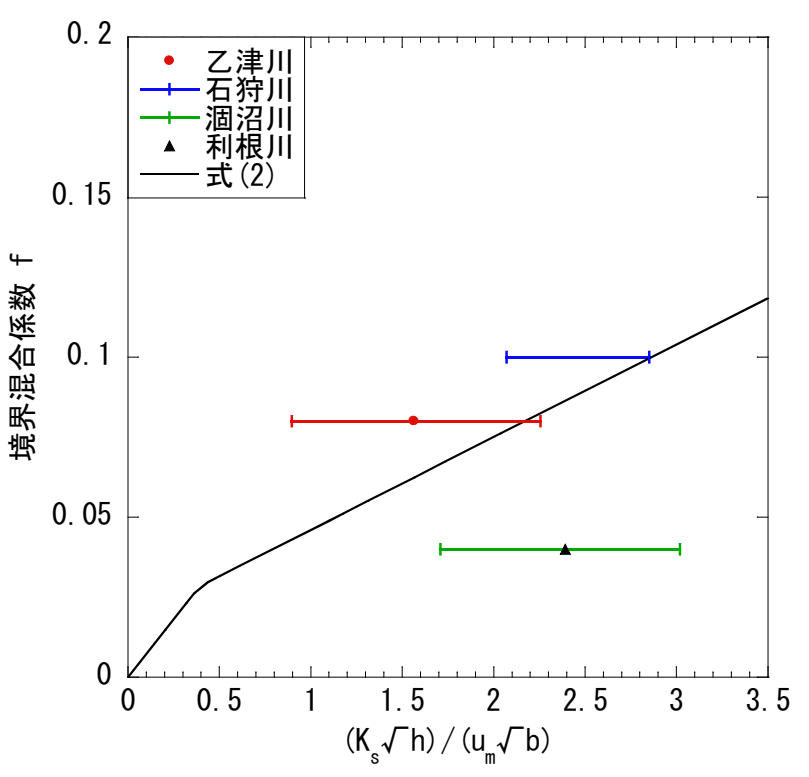

図-5 境界混合係数と無次元パラメータとの関係

を, エラーバーは樹木面積割合の最大值, 最小值を示 している．なお，石狩川については代表的な樹木繁茂 状況の範囲のみを示している.これより，境界混合係数 $f$ は，樹木繁茂面積の割合力増加すると大きくなり，樹 木面積の割合が $1 \%$ 近くになると光の増加率は減少する ことがわかる.乙津川では樹木繁茂面積の割合は 0.3 $1.0 \%$ であることから，境界混合係数は $f=0.06 \sim 0.12$ の範囲にあり, 平均的な樹木面積の割合に応じた境界 混合係数 $f$ は 0.08 であることがわかる . また，石狩川 11) , 涸沼川12) , 利根川13)についてみると，乙津川を対 象に求められた境界混合係数 $f$ と樹木面積の割合との 関係を表す曲線付近にデータがちらばることがわかる． これは, 境界混合係数が, 樹木の繁茂位置や形状など の各河川の河道の特性に応じて変化するためと考えら れる. 実際, 境界混合係数の検討事例を見ると, $f$ 值は 0.01 0.37 程度の幅を持っている1). したがって，ここ で得られた関係は乙津川に限定されるものだと考えら れる.

光こで, 理論的に求められた式 $(2)^{2)}$ と乙津川の平均 的な $f$ 值との適合性を調べたものが図 -5 である . 先ほ どと同樣に , 図中には石狩川 ${ }^{11)}$, 涸沼川 ${ }^{12)}$, 利根川133 の樹木混合係数 $f$ についても併せて示している . これ より，いずれの河川についても式 (2) 周辺にデータがあ ることから，式(2)の関係に概ね従っていること，また， 式 (2) は第 1 近似として十分であることが確認できる .

以上の検討から，乙津川での平均的な境界混合係数は $f=0.08$ と考えられる. 乥こで, この境界混合係数を用 いて, 平成 $9,11,17$ 年に発生した流量 $\left(\mathrm{H} 9: 572 \mathrm{~m}^{3} / \mathrm{s}\right.$, $\mathrm{H} 11: 725 \mathrm{~m}^{3} / \mathrm{s}, \mathrm{H} 17: 1142 \mathrm{~m}^{3} / \mathrm{s}$ ) の異なる 3 つの出水に 対して痕跡水位に基づき準 2 次元解析の検証を行った . 図-6 は, 平成 17 年の出水での準 2 次元解析の河道中 


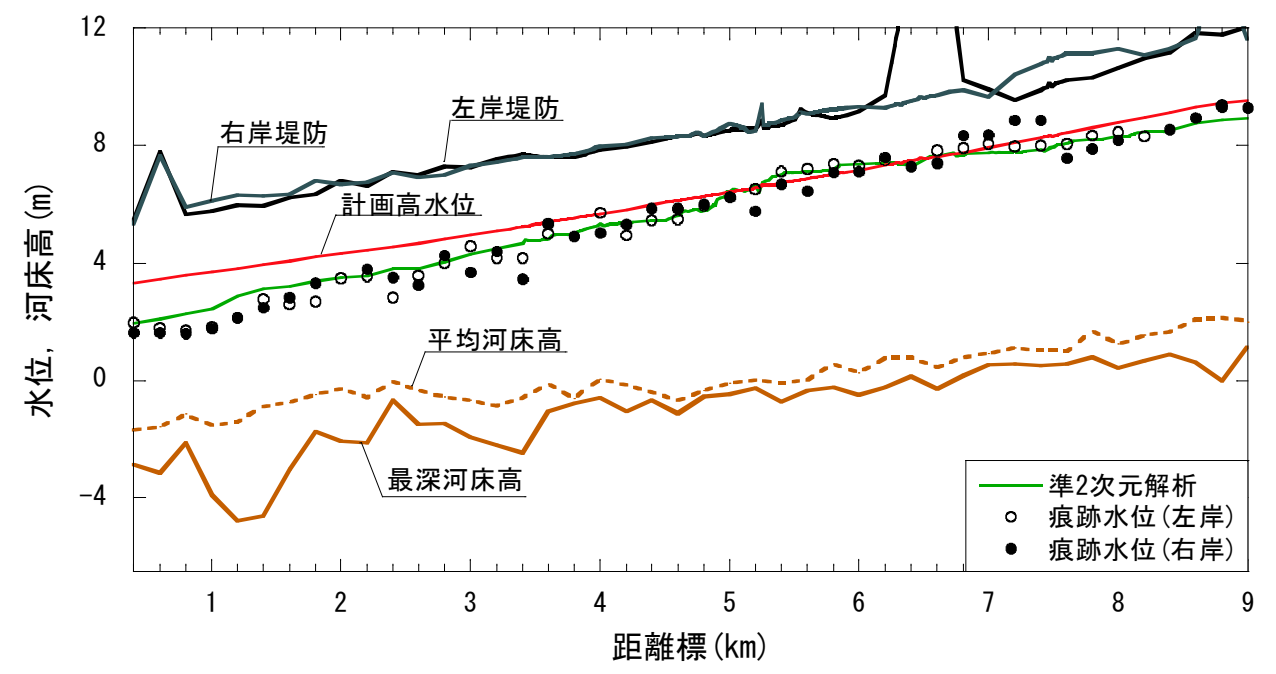

図-6 平成 17 年 9 月の出水時の痕跡水位と準 2 次元解析結果との比較 $(\mathrm{f}=0.08)$

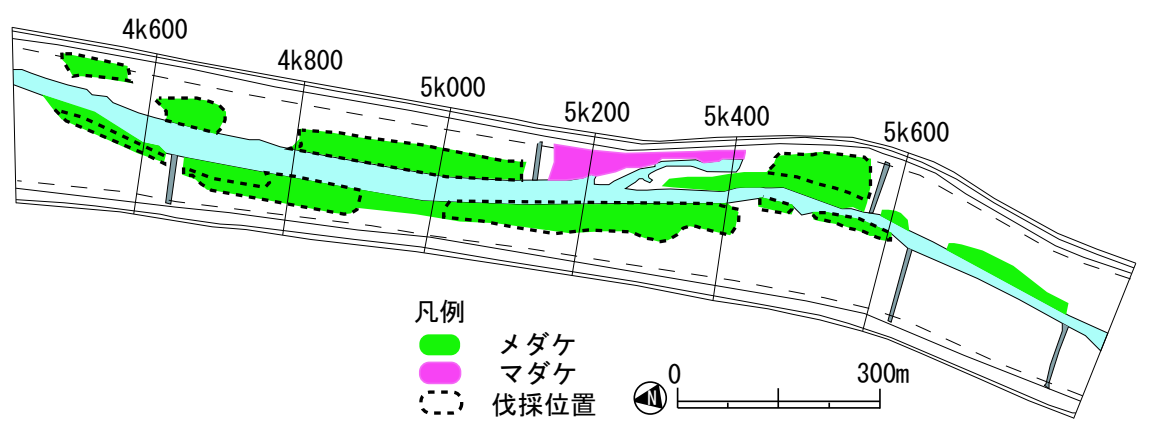

図-7 樹木及び竹林伐採計画案

心軸上の水位と痕跡水位との比較を行ったものである . これより，先ほどの平面 2 次元解析と同樣に痕跡水位 を十分な精度で再現していることがわかる．著者らは， これまでに推奖値 $f=0.10$ を用いて準 2 次元解析を行っ てきた . 全体的には十分な精度で痕跡水位を再現でき るものの，樹木か密生する距離標 $3.4 \sim 5.6 \mathrm{~km}$ 区間では 若干大きく評価していた ${ }^{4)}$. 境界混合係数 $f=0.08$ を用 いた計算ではこのことは改善されている．また，いず れの出水に対しても同程度の精度の結果が得られたこ とから, 乙津川での平均的な境界混合係数が $f=0.08$ で あることの妥当性が確認できる .

\section{(3) 樹木伐採後の境界混合係数 $f$ の推定}

最後に，樹木伐採が境界混合係数 $f$ に及ぼす影響に ついて検討した . 当然のことながら，計画段階で樹木 伐採後の痕跡水位は存在しないために，樹木伐採によ る $f$ 值を検討することは計画を行う上で有用であると 考えられる .

伐採対象区間は，樹木が最も繁茂する距離標 4.6〜 $5.6 \mathrm{~km}$ である . 間伐等を行う場合には，図-4に従えば， $f$ 值はおおよ光予測できるので，ここでは樹木の伐採 は区域伐採とした . 樹木の幅方向に $1 / 4,1 / 2,3 / 4$ と した場合と図一7に示す「樹木及び竹林伐採計画案」に

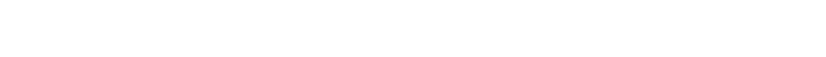
比へ，約 $0.25 ， 0.30 ， 0.50$ および 0.75 倍となっている. 流量は計画高水流量とした .

まず，樹木伐採後の平面 2 次元解析を行い，次に準 2 次元解析を行い，この結果と一致するような $f$ 值を 求めた . 図-8 は, 各距離標での平面 2 次元解析と準 2 次元解析の水位を比較したものである.いずれも直線 上にあり, 平面 2 次元解析と準 2 次元解析とが一致し ていることがわかる .なお，樹木幅を $1 / 4,1 / 2,3 / 4$ とした場合と「樹木及び竹林伐採計画案」の場合 4.6 $6.0 \mathrm{~km}$ の水位の低下率は 13〜18\%であった .

平面 2 次元解析と一致した場合の境界混合係数 $f$ と 樹木伐採量を調べたものが図-9である.いずれの伐採 も，境界混合係数 $f$ 值は大きな変化はなく, $f=0.08$ の 一定値となることがわかる.これは，乙津川の樹木の平 均的な透過係数 $K_{s}=6.5(\mathrm{~m} / \mathrm{s})$ であり, この程度の透 過係数であれば樹木幅による境界混合係数 $f$ の変化が 小さいためと考えられる .このことは，樹木によるせ ん断応力により水位上昇が引き起こされている河道で あれば，樹木伐採を行ったとしても水位低下が生じる 可能性が低いことを示唆している.しかしながら，乙 津川では低下率は 13〜18\%であり，乙津川の樹木伐採 に伴う水位低下は, 河積の増加が主な要因であり，境 


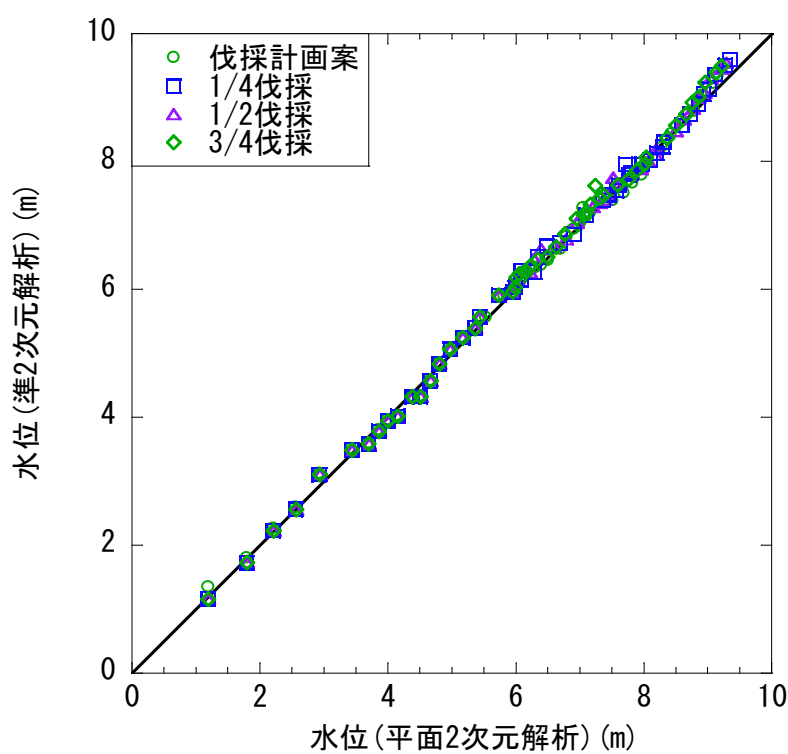

図-8 平面 2 次元解析と準 2 次元解析との比較 (樹木伐採時)

界混合係数 $f$ の変化によるものではないと考えられる 以上のように，乙津川については，樹木を区域伐採 する場合には, 境界混合係数 $f=0.08$ としても良いと考 えられる 。

\section{6. おわりに}

本研究では, 乙津川の平均的な樹木境界混合係数 $f$ の推定を行った後, この $f$ 值を用いた準 2 次元解析の 予測精度について検討した．また，樹木伐採が樹木境 界混合係数 $f$ に及ぼす影響を数值シミュレーションに 基づき検討した . 光の結果，乙津川の平均的な樹木境 界混合係数 $f$ の值は $f=0.08$ であること，この $f=0.08$ を用いれば，流量の異なった 3 つの出水に対する痕跡 水位を再現可能であること, また, 数值シミュレーショ ン結果に基づけば, 間伐を行う場合には図-4の関係を， 区間伐採を行う場合には $f=0.08$ を用いれば樹木伐採後 の水位を予測できること，などの乙津川の樹木管理を 行う上で有用な知見が得られた．今後は，治水機能を 有する樹木，水位上昇や堤防沿いの高速流などの治水 上問題を生じさせる可能性がある樹木を抽出し, 大野 川・乙津川の適切な樹木管理法について検討する予定 である。

謝辞： 本研究は, 河川懇談会の活動の一環として, 国 土交通省大分河川国道事務所と共同で研究を行ったも のである.本研究を実施するに当たり，大分河川国道事 務所の関係各位には現地調査の実施やデータの提供な ど多大な協力を得た . また，九州工業大学工学部生柳 善之君にはデータ作成を行うにあたり協力を得た .こ こに記して感謝の意を表します。

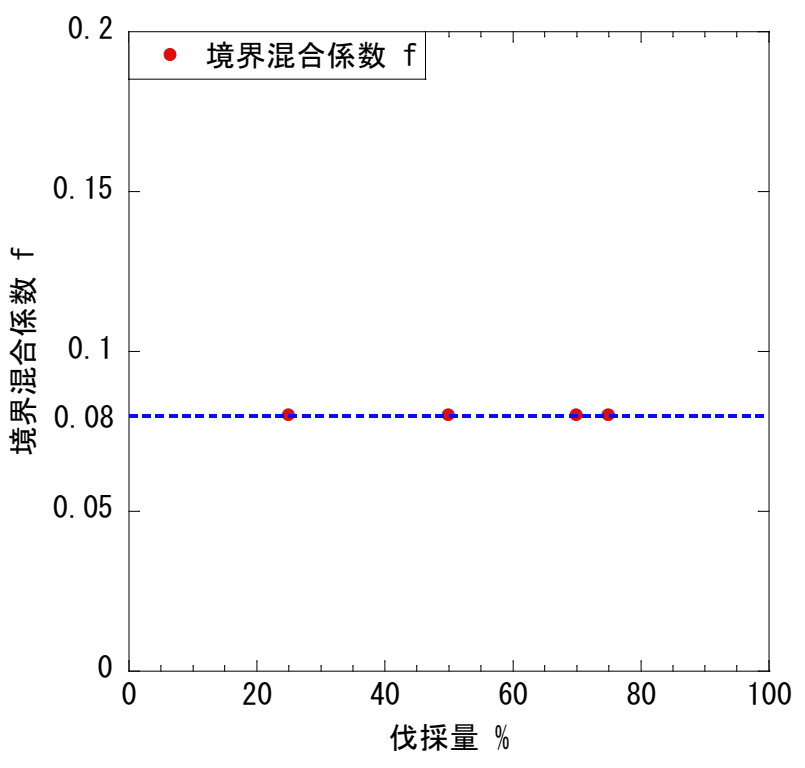

図-9 境界混合係数と伐採量との関係

参考文献

1) 財団法人リバーフロント整備センター (編) : 河川にお ける樹木管理の手引き, 山海堂, 1999.

2) 福岡捷二, 藤田光一：洪水流に及ぼす河道内樹木群の水 理的影響, 土木研究所報告, 第 180 号-3, pp. 129-190, 1990.

3) 福岡捷二, 渡邊明英, 田端幸輔, 風間聡, 牛膓宏 : 利根川・ 江戶川分派点を含む区間における流量ハイドログラフと 粗度係数・樹木群透過係数の評価, 水工学論文集, 第 50 巻, pp. 1165-1170, 2006.

4) 重枝末玲, 朝位孝二, 坂本洋, 長太茂樹, 秋山壽一郎, 樋 口直樹, 重岡広美, 德永智宏 : 樹木群を考慮した平面 2 次 元数值モデルによる乙津川の洪水流解析, 水工学論文集, 第 50 巻, pp. 1171-1176, 2006.

5) 重枝末玲, 朝位孝二, 坂本洋, 長太茂樹, 秋山壽一郎, 樋 口直樹, 重岡広美, 德永智宏 : 大野川と炎の派川の乙津 川を包括した平面 2 次元洪水流解析と河道内樹木が乙津 川の分流量に及ぼす影響, 河川技術論文集, 第 12 巻, pp. 85-90, 2006.

6) 国土交通省 九州地方整備局 大分河川国道事務所 : 台風 14 号 大分川 ·大野川の出水状況平成 17 年 9 月 4 日 6 日, 2005.

7) 重枝末玲, 秋山壽一郎 : 数値シミュレーションに基づく 堤防に沿った樹林帯の治水機能の検討, 土木学会論文集, No. 740/II-64, pp. 19-30, 2003.

8) 財団法人国土技術研究センター: 河道計画シミュレータ WebSite, http://kasen-keikaku.jp/index.html, 2004.

9）国土交通省 九州地方整備局 大分河川国道事務所: 大野 川河道技術資料平成 14 年 3 月, 2002 .

10）国土交通省 九州地方整備局大分河川国道事務所 - 九建 設計株式会社 : 乙津川定期縦断測量 (植物調査) 報告書, 2005.

11）福岡捷二, 藤田光一, 新井田浩 : 樹木群を有する河道の洪 水位予測, 土木学会論文集, Vol. 447/II-19, pp. 17-24, 1992.

12) 福岡捷二ら: 涸沼川における洪水流と河床変動の研究, 土 木研究所報告, 第 180-2 号, pp. 35-128, 1990.

13）福岡捷二, 渡邊明英, 上阪恒雄, 津森貴行 : 低水路河岸 に樹木群のある河道の洪水流の構造 - 利根川新川通昭和 56 年 8 月洪水 -, 土木学会論文集, Vol. 509/II-30, pp. 79-88, 1995.

(2006. 9. 30 受付) 